\title{
Struggling with Lack: A Lacanian Perspective on Organizational Identity
}

\author{
Michaela Driver, Ph.D. \\ Professor of Business Administration \\ Western State College of Colorado \\ Department of Business, Accounting \& Economics \\ Borick Business Building, Office 221 \\ Gunnison, CO 81231 \\ Phone: 970-943-2673 \\ Email: mdriver@western.edu
}

Key Words: Organizational Identity, Psychoanalysis, Lacan, Individual Identity

\section{Biographical Note:}

Michaela Driver is Professor of Business Administration at Western State College of

Colorado where she teaches Organizational Behavior and Human Resource Management.

Michaela researches alternative and psychoanalytic approaches to a wide range of organizational topics. In the past, her work has covered topics like organizational learning, emotions, psychoanalytically-grounded organizational interventions, spirituality, corporate social responsibility, and embodied subjectivity in organizations. Journals in which Michaela has published include Human Relations, Management Learning, Journal of Organizational Change Management, Tamara, Journal of Business Ethics, Journal of Management Inquiry and Organization. Her most recent research projects examine how leadership is constructed in and through organizations and storytelling as a method for exploring experiences of organizational change. She serves on the editorial boards of Tamara, Management Learning and Journal of Management Inquiry. 


\title{
Struggling with Lack: A Lacanian Perspective on Organizational Identity
}

\author{
Abstract \\ The purpose of this paper is to contribute to research on organizational identity by \\ developing a psychoanalytic perspective. In particular, the author draws on Lacanian \\ theorizing to explore how organizational identity discourse is informed by imaginary \\ constructions of subjectivity. It is proposed that the collective construction of coherent, \\ unitary and definably organizational identity discourse is validated by and validates \\ conscious but illusory constructions of the self. The resulting discourse is inevitably \\ disrupted by unconscious subjectivity and invariably fails. Therefore, the collective \\ construction of fragmented, dynamic and emergent organizational identity discourse is \\ equally inevitable. While such discourse can be illusory, it also contains the opportunity \\ for engaging in liberating struggles with identity as lack. The implications of this \\ perspective for the theory and practice of organizational identity are discussed.
}




\section{Introduction}

Organizational identity has long been recognized as a significant concept in organizational studies (Brown, 2001) that has recently received increased attention (Haslam, Postmes and Ellemers, 2003) as a root construct of growing importance (Albert, Ashforth and Dutton, 2000). While its core definition of being the central, enduring and distinctive characteristics of the organization has changed little since its inception over 20 years ago (Albert and Whetten, 1985), various researchers have taken different views on how to interpret these characteristics and there continues to be vibrant dialog about what organizational identity is or should be (Corley 2004; Corley, Harquail, Pratt, Glynn, Fiol and Hatch, 2006; Gioia, Schultz and Corley, 2000a).

The present paper does not seek to revive or resolve definitional debates in the field (Corley et al., 2006) but instead offers an alternative perspective on organizational identity in which such debates serve to address symptoms of an underlying but, to date, under-explored dynamic. Specifically, the paper suggests that current debates on organizational identity in the field reflect less the efficacy of certain approaches to or assumptions about organizational identity over others (Hatch and Yanow, 2007) but rather an underlying dynamic of identity that may not be captured in such approaches. Prior research on organizational identity has advanced the notion that cognitive conceptions of identity, or how we consciously think about and articulate identity, are not sufficient to address less conscious identity processes and that therefore a psychoanalytic understanding should be added (Brown, 1997; Brown and Starkey, 2000a;b; Diamond, 1993; Schwartz, 1990). The present study follows this suggestion and introduces a Lacanian perspective on organizational identity (Lacan, 1977a;b; 1988a;b; 1991; 2001). 
This perspective builds on but also differs from prior psychoanalytically-informed studies of organizational identity focusing on a Freudian approach with an emphasis on interpretation and perhaps intervention (Armstrong, 1997; Carr and Zanetti, 1999; Diamond, 1988; Gabriel et al., 1999). By contrast, as I will explain later, the perspective developed here places more emphasis on language and the indeterminacy of identity and desire but also, importantly, on the impossibility of making specific interpretations for solving problems such as how organizational identity may be understood and adjusted to become more functional.

The most important contribution the Lacanian perspective is intended to make here is to highlight that what has been under-explored in the theory and practice of organizational identity to date is the imaginary character of all organizational identity discourse. That is, regardless of whether organizational identity is unitary or plural, homogeneous or heterogeneous, permanent or temporary, contested or uncontested (Corley et al., 2006), it is constructed around the illusion or fantasy that the self can be defined and fulfilled. Put differently, any answers to questions about who we are and what we want as an organization are just as imaginary as answers to questions about who individuals are and what they want.

From a Lacanian point of view, which I develop in more detail later, such answers are imaginary because they constitute a conscious effort to cover up an unconscious lack in the subject that cannot be overcome (Lacan, 1988a;b). In this sense it is impossible to know who we are or obtain what we want because as soon as we do, it becomes apparent that our answers routinely fail and that what we had desired does not bring us the fulfillment we seek. All subjects are divided between the conscious effort to know 
identity and fulfill desire and the unconscious disruptions that inevitably make such efforts futile. Lacan's greatest insight was perhaps to build on this Freudian conception of subjectivity and to focus not on how this division can be overcome or at least compensated for but rather to point out that this division is structural rather than personal yet may still have personal benefits for each subject.

The problem, from this perspective, then becomes not that we cannot find answers to who we are or what we want but that we fail to recognize how important and an in many ways enjoyable it is that we fail to do so. It is enjoyable not in the sense in which we might commonly construct enjoyment but in the sense that we come closest to feeling intensely alive, to an experience of who we are as subjects and to being at our most creative and powerful, in other words closest to experiencing what Lacan referred to as jouissance (1988b) when we struggle again and again with how we cannot say who we are or obtain what we want.

I will argue that the same applies to organizational identity discourse. As we collectively narrate the central, enduring and distinctive characteristics of an organization (Whetten, 2006) regardless of how many authors may participate or how situated organizational autobiographical acts (Czarniawska-Joerges, 1996:163) may be, we not only construct imaginary answers about identity and desire, we also, importantly, have opportunities to experience jouissance in their failures. In this sense, it misses the point entirely to argue about whether organizational identity is unitary or plural, homogeneous or heterogeneous, permanent or temporary, contested or uncontested (Corley 2004; Corley et al., 2006; Gioia et al., 2006a). From a Lacanian perspective, organizational identity discourse is always all of those things and inevitably divided between conscious 
efforts to articulate and fix identity and desire and the impossibility of ever doing so (Clegg, Rhodes and Kornberger, 2007). But this does not make organizational identity discourse better or worse, right or wrong.

The imaginary character as well as the inevitable failures of the imaginary construction of organizational identity discourse are not personal or collective shortcomings that can be corrected or compensated for. In the end, there is only lack and the ever-present nothingness of work, organization and self (Arnaud and Vanheule, 2007). Organizational identity discourse is always sucked up in this lack but it is also precisely this lack that holds much potential for empowerment and liberation (HolmerNadesan, 1997). When we shift our focus from denying or correcting for the imaginary character of organizational identity discourse, we may come to appreciate the importance of our struggles with this lack and the power and creativity they contain.

In short, the paper hopes to contribute an alternative perspective that highlights, as one reviewer for this paper described it, "an interesting and counter-intuitive windfall effect" of organizational identity discourse by suggesting that what is most constructive about this discourse is not that it is forever moving toward imaginary fixation and that in failing to do so it remains a continuously evolving and plurivocal narrative (CzarniawskaJoerges, 1996) but that it allows "subjects to experience...new possibilities of personal/professional disengagement and engagement by facing up to the dimension of identity as lack". The paper proceeds as follows. First, I review key Lacanian concepts used in the next section to examine organizational identity discourse as an imaginary construction. I discuss how this construction inevitably fails but also how this failure 
offers opportunities for creative struggles with lack. The paper concludes by outlining implications and new directions for the theory and practice of organizational identity.

\section{Lacan and Identity}

In this review I will follow the approach developed in prior applications of psychoanalytic concepts to the study of organizational identity and give only a brief overview of Lacanian theorizing while acknowledging that this does not nearly exhaust the wealth of psychoanalytic thought available for application (Brown, 1997; Brown and Starkey, 2000a). As different from prior applications, however, the emphasis here is on Lacanian approaches, a particular and not widely used brand of psychoanalytic theorizing that builds on but also extends Freudian perspectives particularly with a view toward the importance of language (Lacan, 2001). This theorizing was selected because it offers a focus on discourse suitable to the discursive nature of organizational identity (Brown, 2006; Brown and Starkey, 2000a; Hatch and Schultz, 2002; Whetten, 2006).

Additionally, it has been shown as highly relevant to a deeper understanding of a number of organizational issues from a broad understanding of organizational dynamics to particular insights about leadership, power, stress and motivation (Arnaud, 2002; 2003a; Arnaud and Vanheule, 2007; Jones and Spicer, 2005; Driver, 2005; Roberts, 2005; Vanheule, Lievrouw and Verhaeghe, 2003).

In my review of concepts, I will draw on Lacan's major theoretical works (Lacan, 1977a;b; 1988a;b; 1991; 2001) and the many interpretations and applications of his work by others (i.e. Benvenuto and Kennedy, 1986; Bowie, 1991; Bracher, 2000; Brousse, 1996; Elliott and Frosh, 1995; Fink, 1995; 1996; 2000; 2004; Gallop, 1985; Loose, 2002; Muller and Richardson, 1982; Nobus, 2002; Ragland, 1996; Rustin, 1995; Soler, 1996; 
Vanheule, 2006; Verhaeghe, 1999; 2001; 2006). Due to space constraints I develop the Lacanian framework only briefly. Further introductions are also provided elsewhere (e.g. Arnaud, 2002; 2003a;b; Arnaud and Vanheule, 2007; Driver 2008; 2009).

The imaginary refers to a discourse in which the individual is stuck in the fantasy or illusion that the self is a definitive and stable object, an identity one can refer to that has a clear existence and provides one with the power to control one's circumstances, the self and others. The development of the discourse of the imaginary originates in Lacan's work on the mirror stage (1977a). It refers to a child's attempts at reintegrating its experience of the world, which makes it feel helpless, disjointed and anxious, with its earlier experience in the womb of completeness, unity and state of being whole and fulfilled. The mirror image, whether literal as reflection of the physical self or figurative as reflection of a socially constructed self, is a distortion, a "miscognition" (Muller and Richardson, 1982: 31). The self that is constructed around this image is an illusory object of the ego.

Language and discourse in turn constitute the symbolic order, the structure imposed on every individual prior to birth through social conventions handed down for generations (Fink, 1995). What remains of the primal subject is only the act of submersion in the symbolic order, the unconscious trauma of the loss of primal fulfillment. As such, that which truly and uniquely marks the person is a loss or lack (Ragland, 1996). This lack cannot be filled in the symbolic order because it is marked by lack or loss due to the existence of the real, i.e. the physical, bodily, undifferentiated primal subject prior to language. As we engage in conscious discourse, articulating the self, trying to express our desires, we are alienated by a symbolic order in which we can 
articulate who we are and what we want only in the words of others. Yet we are unable to jettison or move beyond this order. Therefore, we continue to experience alienation and otherness in our self-constructions and are unable to satisfy our desires. Put differently, the immediate experience of the world and the return to the original state of wholeness and fulfillment we long for is always missing in how we articulate the self and its desires. So all we are left with are articulations that are not us, somehow removed and importantly continuously lacking.

Lacanian analysis offers no cure for this experience but rather invites us to take a different subject position relative to the inevitable failures of the imaginary. It invites us to experience our inability to find answers to who we are and what we want not as a personal shortcoming that can be overcome but rather as a structural condition. In particular, a Lacanian perspective invites us to experience how the many failures that mark our conscious discourse are not errors of speech but important aspects of our selfconstruction. They mark how we continue to reiterate and circle around fundamental lack and, importantly, how each of us does so uniquely and creatively.

The amplification of and reflection on the failures of our imaginary selfconstructions offer the opportunity for experiencing how powerful we are as subjects of the unconscious. As our conscious, imaginary self-constructions fail, who we are as subjects of the unconscious, or beyond our conscious knowledge, is reasserted again and again. In noticing this we can experience that our conscious constructions and the objects into which we fashion our desires and our selves can never define and therefore contain us. In this sense it is the very disruptions and failures of our imaginary discourse that constitute the opportunity to be at our most liberated, creative and powerful or, in other 
words, to experience jouissance not as ordinary enjoyment but rather as an experience of something similar to our lost wholeness and state of being fulfilled (Arnaud, 2003b).

In short, while imaginary self-constructions are necessary and inevitable in the course of how we consciously construct the self, it is equally necessary and inevitable that we encounter their failure. The latter experience does not free us from the alienation and otherness that accompany imaginary self-constructions as we cannot consciously know who we really are as subjects. But in experiencing that we are not who we consciously say we are and can never articulate what we really want, we can come to find some enjoyment in how powerful we are as subjects. Consequently, a Lacanian perspective invites us to notice the imaginary nature of identity discourse not so we can uncover who we really are but to have the opportunity to experience its repeated failures as creative and empowering struggles with lack.

\section{Imaginary Organizational Identity}

Organizational identity refers to a discourse (Whetten, 2006) or the narrative construction of the organization's central, enduring and distinctive characteristics, a conversation that is socially constructed and can include internal and external stakeholders (Brown, 2006; Hatch and Schultz, 2002; Scott and Lane, 2000a). This discourse spans various levels of analysis as individuals can draw on collective or organizational discourse to construct positions for themselves and, in turn, individual narratives contribute to collective discourse (Brown, 2006). Therefore, while organizational identity discourse is different from individual identity discourse, the two are mutually constituted (Brown, 2001; 2006; Gioia, Schultz and Corley, 2000b). 
In view of this mutual constitution, I am suggesting that how individuals construct subjectivity in discourse informs organizational identity discourse and visa versa and that organizational identity discourse is implicated in the imaginary construction of self and organization. Particularly, collective discourse in which a unitary, coherent and definable organizational identity is constructed validates and is validated by the identity that individuals commonly construct in conscious but imaginary fashion. From a psychoanalytic perspective, it is therefore highly relevant to acknowledge that organizational identity is "illusory" (Gioia et al., 2000a: 64). It is illusory not because it is factually untrue but because it is built on an imaginary order in which answers can be provided about who we are and what we want.

Consider, for example, the initial definition of organizational identity as the central, enduring and distinctive characteristics of an organization (Albert and Whetten, 1985). This has long been taken to imply that organizational identity is a unitary construct exerting considerable force to maintain a consistent and coherent organizational identity over time (Whetten, 2006). While research has since allowed for more flexible approaches, the idea remains attractive that there is an organizational identity that forms a unitary essence that is more stable than it might seem (Corley et al., 2006; Scott and Lane, 2000b). Moreover, while the ability to adapt identity to changing environmental demands is considered crucial for organizational success (Gioia et al., 2000a; Corley and Gioia, 2004; Corley et al., 2006), it is considered equally and at times more important to retain a unitary identity that provides recognition (Whetten, 2006), legitimacy and possibly competitive advantage (Sillince, 2006). 
Additionally, a single identity is considered to put fewer resource strains on organizations and as enabling decisive organizational action (Haslam et al., 2003; Pratt and Foreman, 2000). A single and clearly definable identity is also thought to enhance loyalty, member commitment and identification creating a sense of belonging and providing an anchor in turbulent times that organizational members not only become attached to but will go to some lengths to defend (Brickson, 2005; Corley and Gioia, 2004; Dutton and Dukerich, 1991; Elsbach and Kramer, 1996; Elsbach and Battacharya, 2001; Fiol, 2002; Glynn, 2000; Haslam et al., 2003).

What has been under-explored to date is that the hallmarks of a coherent, unitary and clearly definable organizational identity are, from a psychoanalytic perspective, indicators of identity discourse firmly enmeshed in an imaginary order. In this order the organization is part of the fundamental fantasy that the self can be whole and fulfilled as opposed to divided and lacking (Arnaud and Vanheule, 2007). The discourse of belonging, identification with and commitment to the organization facilitates subject positions in which the individual has a definitive, stable and knowable identity and in which organizational legitimacy (Sillince, 2006) validates identity and fulfills one's wishes for belonging and recognition. In this sense the mutual constitution of imaginary organizational and individual identity discourses rests in the objectification and alienation of self and other. The organization becomes an object visa vi the self that must be fixed in a certain way to validate the conscious answers constructed for who the self is and what it wants while the self is also an object in service of maintaining a stable, coherent and definable collective identity. Both must be defended to maintain the imaginary order even when this does not seem to be constructive (Brown and Starkey, 2000a). 
From what I have suggested so far, it seems that coherent, unitary organizational identity discourse is informed by and informs imaginary constructions of self and organization. I now turn to what might be defined as the opposite view of organizational identity. Specifically, I examine organizational identity discourse that allows for more plurality. For example, some have suggested that organizational identity discourse consists of or should allow for a plurality of identity constructions to ensure that it remains highly adaptive to change (Gioia et al., 2000a) or capable of meeting new demands from the environment by adopting multiple identities (Corley, 2004; Fiol, 2002; Gioia and Corley, 2004; Gioia et al., 2000a). As a result organizations should encourage members to develop more temporary and situated organizational identifications (Fiol, 2001) that facilitate more frequent changes of identity meanings (Gioia et al., 2000a). Such frequent changes may enable the organization to become more responsive to requisite variety (Brown, 2006) and negotiate more effectively with different stakeholders (Scott and Lane, 2000a) as well as allowing it to navigate and manage a number of identities (Pratt and Foreman, 2000) or conflicting understandings of what the organization's identity should mean (Pratt and Rafaeli, 1997).

Consequently, identity has been characterized as diverse and changing (Albert et al., 2000) as the organization's question "Who am I?" (Albert and Whetten, 1985) no longer seems to have just one answer. It has been suggested that there may be as many answers as there are different stakeholders involved (Scott and Lane, 2000a). Moreover, there seem to be more opportunities for those different answers to be noticed as organizational members become concerned with what others think about the organization 
(Dutton and Dukerich, 1991) and more conscious of potential gaps between internal and external identity perceptions (Hatch and Schultz, 2002).

From a psychoanalytic perspective such conceptions of organizational identity indicate the inevitable failure of imaginary identity constructions and imaginary efforts at covering up the lack that is thereby revealed. They indicate the impossibility of collective discourse in which coherent, unitary and definable answers can be constructed about who we are and what we want as well as the impossibility of a collective discourse in which fragmented, plural and dynamic identities furnish more varied but equally imaginary answers. As much as individual, conscious constructions of the self in discourse continue to be disrupted by the unconscious and the fundamental lack that marks individuals, collective discourse, similarly, is continuously disrupted and reflects a lack that cannot be overcome. Whatever reasons may be attached consciously for why a singular, coherent, stable and clearly definable organizational identity fails, such as because the environment changes (Gioia et al., 2000a) or different stakeholders place different demands on the organization (Scott and Lane, 2000a), identity discourse remains indeterminate and fails to fix identity (Clegg et al., 2007). The lack in identity discourse and the resulting alienation and otherness are structural and not personal shortcomings that can be corrected (Lacan, 1988b).

In this sense, multiple, fragmented and/or more dynamic organizational identity discourse (Brown, 2006) results from identity that is talked into being from a desire to fix identity that never quite succeeds (Clegg et al., 2007) and therefore indicates the normal and inevitable disruption of the imaginary order. Every subject encounters such disruptions every day, as we consciously construct imaginary selves and every day, our 
speech is filled with ambiguities, omissions, tangents, and mis-constructions that indicate that our imaginary constructions fail, again and again (Lacan, 1988b). Therefore, I am arguing that organizational identity discourse is always imaginary when answers about identity are provided but also that there are always already opportunities for unsettling this order by noticing how these answers fail. Along those lines, it has been proposed that organizations have more enduring, perhaps more deeply seated, core identities and also more temporary, surface identities (Corley et al., 2006). Similarly, they may have changing identity meanings and stable identity labels (Gioia et al., 2000a) or changing substantive and enduring intangible identity components (Gustafson and Reger, 1995). These in turn stimulate changing situated member identifications to the former and, simultaneously, deeper, more enduring commitments to the latter (Fiol, 2001).

What I am suggesting is that both types of identity discourses do not just exist simultaneously (Corley et al., 2006) but that there is an underlying tension between them worth surfacing and exploring. By doing so, it becomes more transparent that the discourse about the need to change identity meanings (Gioia et al., 2000a) is always also a dialog about how and why existing identity labels fail to convey meaning. Conversely a discourse about the need for changing substantive identity components or what we do (Gustafson and Reger, 1995) is always already a conversation about how intangible identity components no longer represent why and how we do things (Gustafson and Reger, 1995). Finally, the discourse about the need to change situated commitments occurs at the interstice of conversations about what is missing from our enduring commitments (Fiol, 2001). 
In short, I am suggesting that focusing on the imaginary nature of organizational identity discourse provides glimpses of an underlying dynamic that has not been explored. It renders transparent why research finds that there is both a need for a coherent, unitary and stable identity as well as for a more fragmented, plural and dynamic identity in organizations. The former reflects the imaginary order we consciously construct while the latter reflects the inevitable failure of this order and our attempts at correcting this failure but also the opportunity to disrupt the imaginary and experience how any conscious answers we might arrive at, individually and collectively, fail to define and thereby contain us as subjects.

\section{Discussion}

So far I have explored organizational identity discourse as an imaginary construction. I now discuss how insights generated by this perspective connect to and extend recent research particularly on the links between individual and organizational identity, the indeterminacy of identity discourse as well as power and control in organizations (Alvesson and Willmott, 2002; Clegg et al., 2007; Holmer-Nadesan, 1997). Individual identity has long posed problems for researchers and is also a topic for ongoing debate and continued interest (Collinson, 2003). Post-structuralist conceptions of the de-centered subject (Kondo, 1990) posit identity as complex and marked by contradictions and tensions. Identity, it would seem, oscillates between ontological security and the insecurities of multiple, fragmented selves (Collinson, 2003) in a contested struggle that offers opportunities for control and emancipation (Alvesson and Willmott, 2002), coherence and security as well as fragmentation and existential anxiety (Sveningsson and Alvesson, 2003). 
While identity is increasingly important for how power is constituted in organizations (Simon and Oakes, 2006) and as the site for normative organizational controls, due to its fragmented, dynamic and pluralistic nature, organizational control is never total; and dominant organizational discourses are always already contested and contestable as individual identity discourse is fragmented, divergent and elusive (Alvesson and Robertson, 2006; Alvesson and Willmott, 2002; Sveningsson and Alvesson, 2003). Emancipation and resistance of organizational control may therefore be tied to the ambiguities and polyvalence of individual identity work, which unsettles and weakens dominant and coherent, organizational discourses (Thomas and Davies, 2005).

The framework developed here underlines this dynamic suggesting that organizational identity discourse is always already contested because imaginary answers to who we are as an organization are mutually constituted at the interstice of conscious as well as unconscious constructions of individual and collective selves. In particular, they are so constituted at the interstice of failures and disruptions that articulate a fundamental lack, which cannot be covered up or eliminated. It was previously found that organizational identity narratives are always informed by how individuals author and enact their own stories and in the process subjugate to some and resist other narratives and interpretations (Humphreys and Brown, 2002).

A Lacanian view on organizational identity extends these insights by suggesting that what may be referred to as subjugation to discourse, particularly dominant narratives of organizational identity often imposed by organizational elites (Humphreys and Brown, 2002), supports and validates imaginary self-constructions. It is therefore not just an imposition (Humphreys and Brown, 2002) but also a function of the objectification that 
results in the normal course of conscious self-construction. Put simply, subjugation to another's identity narrative, identification with the organization's identity discourse for example (Holmer-Nadesan, 1997), is by definition part of imaginary self-construction. This is also true for resistance. Consciously, constructing a narrative in opposition to another's identity narrative or counter-identification by negating organizational identity discourse (Holmer-Nadesan, 1997) is also imaginary. Therefore, counter-identification (Holmer-Nadesan, 1997) and identification with dominant identity narratives (Humphreys and Brown, 2002) are equally imaginary.

However, resistance is also inherent in the unconscious disruptions of the imaginary and is part of its inevitable failure. This implies that the present framework offers new insights for rethinking resistance and control in organizations (Fleming and Spicer, 2003) with regard to organizational identity discourse. Building on prior research finding that it is the subject's experience of the lack in organizational identity discourse that widens individuals' spaces for action (Holmer-Nadesan, 1997: 59), the present framework suggests that collective identity narratives that amplify the lack of the subject and provide a space for struggles with identity and desire also provide the potential for liberation. A recent study of the identity of professionals in audit firms suggests that organizational norms are upheld to validate the fantasy of a self that is maintained in opposition to these norms (Kosmala and Herrbach, 2006).

The framework developed here adds to these insights that imaginary organizational identity discourse serves not just to validate imaginary self-constructions and thereby provides ontological security (Alvesson and Willmott, 2002) but also to amplify their failure and thereby to heighten the experience of creative struggle and 
empowerment. Particularly, in instances when individuals encounter the lack in the collective discourse (Holmer-Nadesan, 1997), they are thrown back, so to say, on to their own lack and therefore have the liberating experience that work and organizations can never be more than nothing (Arnaud and Vanheule, 2007) or more than a reiteration of lack for the subject.

One way to illustrate this dynamic may be to consider a recent empirical study on organizational identity, namely the case of Westville Institute, an institution of higher education, in which the administration sought to attain university status, an effort that was heavily contested and eventually failed (Humphreys and Brown, 2002). The case provides rich narrative data illustrating how the school's administration sought to develop an organizational identity discourse commensurate with the stable, singular and clearly definable identity of a university and how this failed as university status was never granted and members of the organization continued to resist the administration's efforts to impose it (Humphreys and Brown, 2002). The case seems to illustrate vividly how individual narrators reiterate identity as lack.

The administrators talk about all the characteristics the institute already has that should make it qualify for university status while the status itself is actually missing (Humphreys and Brown, 2002: 431-2). Members of the Institute talk about their lack of inclusion in the organization's identity discourse (Humphreys and Brown, 2002: 434-5), what they are lacking in order to bring the new identity about (Humphreys and Brown, 2002: 435-6) and their lack of attachment to the organization's identity (Humphreys and Brown, 2002: 436-7). As one faculty member describes it:

We're like little satellites now... since this faculty has been created we don't know whether we're part of the faculty... When I'm at work, I want to see this place 
survive and while I'm here I do my best for them, but there's a lot of demoralized people about at the moment... When the buzzer goes at five o'clock, they're out the door (Humphreys and Brown, 2002: 437).

A Lacanian perspective enables us to understand this narrative not just as an example of political contestation and the plurivocal nature of organizational identity discourse (Brown, 2006; Humphreys and Brown, 2002). In particular, it shifts our focus to how organizational identity discourse amplifies this narrator's experience of struggling with the failure of his imaginary identity as working for a place he wants to see survive and for which he wishes to do his best while not knowing whether he is actually part of this organization and working with others for whom work has become just a job. As such, it makes transparent how organizational identity discourse is appropriated as a space for divided subjectivity (Arnaud and Vanheule, 2007). For example, for this particular narrator, it is because and not in spite of the active management of Westville's identity (Humphreys and Brown, 2002) that more rhetorical resources (Fiol, 2002) become available for this space.

The collective narratives about why and how Westville is or is not to be a university amplify his own failed answers about work and self so that they can be heard and reflected on. Put differently, it is not because Westville's identity is to change that he struggles with being demoralized or not feeling part of the organization. But it is because this change stimulates a collective conversation about identity that he can hear how he struggles with these. At the moment that this occurs, he emerges as a creative and powerful subject that cannot be defined by fantasies of work, self and organization. In short, a Lacanian perspective on organizational identity suggests that organizational identity discourse may not be driven by the desire for identity, whether it is fixed or 
otherwise, but rather by the jouissance experienced when failures of imaginary constructions are rendered transparent or audible. To put it bluntly, what we may need most from answers about who we are as an organization is to hear what they fail to tell us about who we are as subjects.

\section{Conclusion}

The purpose of this paper has been to contribute to research on organizational identity by introducing a psychoanalytic, specifically Lacanian, perspective providing insight into underlying and to date under-explored dynamics of organizational identity discourse. In particular, it was argued that organizational identity discourse in which a singular, coherent and definable identity is collectively constructed reflects an imaginary order while more contested and plurivocal organizational identity discourse (Brown, 2006) in which the organization's identity is collectively constructed as consisting of multiple, fragmented and dynamic identities (Fiol, 2001; Gioia et al., 2000a) were examined as indicators of the inevitable failure of the imaginary and efforts to correct this. It was suggested that failure is due to the fundamental lack of all imaginary constructions and that focusing on and exploring this failure provides opportunities for the experience of creative and liberating struggles with lack.

The proposed framework has a number of implications for the theory and practice of organizational identity. First it suggests that a crucial underlying dynamic of organizational identity discourse is missed by conceptualizing it as being either stable, coherent and enduring or dynamic, fragmented and changing, or both (Clegg et al., 2007). This dynamic comes to light when we consider instead that organizational identity may be neither or, what is more to the point, that it is never more than an imaginary 
construction that invariably fails. This in turn implies that what matters about organizational identity discourse is not whether it is more accurate or even more effective that it is stable, coherent and enduring or dynamic, fragmented and changing, or both (Corley et al., 2006; Whetten, 2006). Instead, what matters is that we examine the underlying tensions between such conceptions and how they are talked into being (Clegg et al, 2007) so that we can mark and hold them up for reflection as indicators of failed imaginary constructions. Inasmuch as Lacanian analysis focuses on the ambiguities, omissions, contradictions, unusual constructions, tangents and other failure points of speech to mark, amplify and hold up for reflection the analysand's (person being analyzed) failed imaginary self-constructions (Lacan, 1988a), focusing on the underlying tensions between stable, coherent and enduring versus dynamic, fragmented and changing organizational identity discourses may allow us to amplify and make available for reflection the failure points of organizational identity discourse.

This may provide insight into how lack in this discourse is reiterated in particular instances and how the contested and contestable nature of organizational identity discourse is not only driven by conscious political motivations, such as efforts to dominate discourse and impose a desired identity (Brown, 2006; Humphreys and Brown, 2002), but also by subjects engaged in creative and liberating struggles with lack. In taking this research forward it may therefore be constructive to adopt an integrative approach combining the perspectives advanced by the proponents of identity as a more coherent, stable and unitary discourse (e.g. Albert and Whetten, 1985; Whetten, 2006) as well as those advocating a more dynamic, emergent and plural view (e.g. Brown, 2006; Corley, 2004; Fiol, 2002; Gioia and Corley, 2004; Gioia et al., 2000a; Pratt and Foreman, 
2000; Scott and Lane, 2000a). But rather than looking for a multi-paradigm or multimetaphor description of organizational identity (e.g. Corley et al., 2006; Hatch and Yanow, 2007), a Lacanian view suggests examining change as a failure of stability, fragmentation as a failure of coherence, plurality as a failure of singularity and so forth. That is, rather than putting each discourse into its place, we might look for how each exists in relation to the other.

This has important implications for organizational identity discourse and how power is constituted in and through this discourse in organizations. Counter-identification as a conscious effort to experience lack and widen a space of action likely dissolves into dis-identification and the pursuit on another equally constraining identity discourse (Holmer-Nadesan, 1997). Put differently, social power is constituted via organizational identity discourses (Simon and Oakes, 2006) whenever there is the illusion that one can step outside of them, that there is a private self (Fleming and Spicer, 2003) that can be protected from or defined in opposition or relation to a collective identity. But this power is also contested and contestable by being inside dominant identity discourses and experiencing what they are not (Holmer-Nadesan, 1997). Social power in this sense is not just domination and control via identity discourse (Simon and Oakes, 2006) but importantly the power of subjects to amplify lack.

Future research using various narrative methods (Brown, 2006) may explore in detail how the lack of organizational identity discourse (Clegg et al., 2007; HolmerNadesan, 1997) is reiterated in and through specific narratives at the interstice of changing identity meanings and stable identity labels (Gioia et al., 2000a), changing substantive identity components and enduring intangible identity components (Gustafson 
and Reger, 1995) as well as changing situated member identifications and deeper, more enduring commitments (Fiol, 2001). To pursue this it may also be constructive to build on recent research that explores what happens when a strong organizational identity is missing (Maravelias, 2003). If we examine more closely how individuals fill in for these missing narratives (Maravelias, 2003), we may come closer to understanding how lack is articulated in specific instances and how normative controls serve not just to fill a collective gap (Maravelias, 2003), but a very specific lack of the subject. For example, while responses such as "I don't necessarily see how we're going to get there or what we're doing right now..." (Corley, 2004: 1162) and "It can all get very confusing" (Corley, 2004: 1163) have been interpreted as indicating identity inconsistencies (Corley, 2004), the model developed here suggests that they point to specific instances of how individuals struggle with identity and therefore represent stories and story themes (Brown, 2006) of struggles with lack.

Therefore an important practical implication of the framework I have developed here is that different conceptions of identity discourse bring to light different identity practices. While this may happen through targeted intervention (e.g. Arnaud, 2003; Arnaud and Vanheule, 2007), I think that just exploring the imaginary character of organizational identity discourse enhances our social power not by expanding our role as authors of collective identity narratives (Czarniawska-Joerges, 1996) but by experiencing how we already always appropriate them as acts of creative performativity (Butler, 1993). In this sense all we have to do is to recognize that organizational identity discourse is never just a conceived or a perceived space but a lived space (Lefebvre, 1991) in which 
how we consciously narrate and enact identity (Czarniawska-Joerges, 1996) can never quite capture how we experience it.

This lived space may look and feel very similar to what was illustrated in Nancy Harding's recent essay on the becoming-ness of organization and selves where she goes into much detail describing and reflecting on instances of an interview with a manager in which desire and identity were continuously narrated into being but never achieved (Harding, 2007). From this perspective, experiencing moments of jouissance in organizational identity discourse may involve no more than becoming present to what already is. That is, if we listen carefully to the ambiguities, omissions, contradictions, unusual constructions, tangents and other failure points in our conversations about who we are and what we want collectively and, instead of moving to interpretation or corrections, just take a moment to repeat them, amplify and reflect on them, as Nancy did, we might notice the many failed illusions but also the power (of becoming) they contain (Harding, 2007).

In the lived space of organizational identity discourse, we may hear ourselves saying "I don't necessarily see how we're going to get there or what we're doing right now..." (Corley, 2004: 1162) and "It can all get very confusing" (Corley, 2004: 1163) as creative and powerful transgressions (Butler, 1993) through which we appropriate the collective search for identity to encounter the lack in our own. This encounter is empowering and liberating (Holmer-Nadesan, 1997) not because we resist what is imposed but because we can feel ourselves as being alive and creative in our very failure to define who we are and what we want. 
In short, a number of new avenues for understanding organizational identity discourse and particularly its relation to individual identity work and power in organizations (Alvesson and Willmott, 2002) are opened up when we supplement conceptualizations of organizational identity as a strategic performance of discursive norms and structures to create and exploit markets (Clegg et al., 2007: 510) with approaches examining them as collective conversations that divided subjects can thrive on (Arnaud and Vanheule, 2007). By exploring the imaginary character of organizational identity discourse and its inevitable failures not as mistakes we must do better at managing but rather as lived spaces (Lefebvre, 1991) where identity, desire and power are talked into being (Clegg et al., 2007) by unique and powerful subjects, we may yet come to appreciate the illusory nature of organizational identity (Gioia et al., 2000a) as an important organizational excess we create and play with (Bataille, 1988). Without the myriad resources organizations supply us with to construct imaginary collective identity (Fiol, 2002), we would have many fewer opportunities to encounter the only thing that may be referred to as authentic about ourselves, namely who we are not who we just said we are and do not want what we just said we wanted again!

\section{References}

Albert, S. 1995. Towards a theory of timing: An archival study of timing decisions in the Persian Gulf War. In L.L. Cummings and B.M. Staw (Eds.), Research in Organizational Behavior: 1-70. Greenwich, CT: JAI.

Albert, S. and Whetten, D.A. 1985. Organizational identity. In L.L. Cummings and M.M. Staw (Eds.). Research in Organizational Behavior, Vol. 7: 263-295. Greenwich, CT: JAI.

Albert, S., Ashforth, B.E. and Dutton, J.E. 2000. Organizational identity and identification: Charting new waters and building new bridges. Academy of Management Review, 25(1): 13-17. 
Alvesson, M., and Robertson, M. 2006. The best and the brightest: The construction, significance and effects of elite identities in consulting firms. Organization, 13(2): 195224.

Alvesson, M. and Willmott, H. 2002. Identity regulation as organizational control: Producing the appropriate individual. Journal of Management Studies, 39(5): 619-644.

Armstrong, D. 1997. The institution-in-the-mind: Reflections on the relation of psychoanalysis to work with institutions. Free Associations, 7(41): 1-14.

Arnaud, G. 2002. The organization and the symbolic: Organizational dynamics viewed from a Lacanian perspective. Human Relations, 55(6), 691-716.

Arnaud, G. 2003a. A coach or a couch? A Lacanian perspective on executive coaching and consulting. Human Relations, 56(3): 1131-1143.

Arnaud, G. 2003b. Money as signifier: A Lacanian insight into the monetary order. Free Associations, 10(53): 25-43.

Arnaud, G. and Vanheule, S. 2007. The division of the subject and the organization: A Lacanian approach to subjectivity at work. Journal of Organizational Change Management, 20(3): 359-369.

Bataille, G. 1988. The accursed share. New York: Zone Books.

Baum, H. 1990. Organizational membership. Albany, NY: SUNY Press.

Benvenuto, B. and Kennedy, R. 1986. The works of Jacques Lacan. New York: St. Martin's Press.

Boje, D. M. 2001. Narrative methods for organizational and communication Research. London: Sage.

Boje, D.M., Oswick, C., and Ford, J. 2004. Language and organization: The doing of discourse. Academy of Management Review, 29(4): 571-577.

Bowie, M. 1991. Lacan. Cambridge, MA: Harvard University Press.

Bracher, M. 2000. How analysis cures according to Lacan. In Malone, K. R., and Friedlander, S.R. (Eds.). The subject of Lacan: A Lacanian reader for psychologists. Albany, NY: State University of New York Press: 189-207.

Brickson, S.L. 2005. Organizational identity orientation: Forging a link between organizational identity and organizations' relations with stakeholders. Administrative Science Quarterly, 50: 576-609. 
Brousse, M. 1996. The imaginary. In Feldstein, R., Fink, B., and Jaanus, M. (Eds.)

Reading seminars I and II: Lacan's return to Freud. Albany, NY: State University of New York: 118-129.

Brown, A.D. 1997. Narcissism, identity and legitimacy. Academy of Management Review, 22(3): 643-686.

Brown, A.D. 2001. Organization studies and identity: Towards a research agenda. Human Relations, 54(1): 113-121.

Brown, A.D. 2006. A narrative approach to collective identities. Journal of Management Studies, 43(4): 731-753.

Brown, A.D. and Starkey, K. 2000a. Organizational identity and learning: A psychodynamic perspective. Academy of Management Review, 25(1): 102-120.

Brown, A.D. and Starkey, K. 2000b. Toward integration. Academy of Management Review, 25(1): 148-150.

Chreim, S. 2005. The continuity-change duality in narrative texts of organizational identity. Journal of Management Studies, 42(3): 567-593.

Clegg, S. R., Rhodes, C. and Kornberger, M. 2007. Desperately seeking legitimacy: Organizational identity and emerging industries. Organization Studies, 28(4): 495-513.

Collinson, D.L. 2003. Identities and insecurities: Selves at work. Organization, 10(3): 527-540.

Corley, K.G. 2004. Defined by our strategy or our culture? Hierarchical differences in perceptions of organizational identity and change. Human Relations, 57(9): 1145-1177.

Corley, K.G. and Gioia, D.A. 2004. Identity ambiguity and change in the wake of a corporate spin-off. Administrative Science Quarterly, 49: 173-208.

Corley, K.G., Harquail, C.V., Pratt, M.G., Glynn, M.A., Fiol, C.M. and Hatch, M.J. 2006. Guiding organizational identity through aged adolescence. Journal of Management Inquiry, 15(2): 85-99.

Czarniawska-Joerges, B. 1996. Autobiographical acts and organizational identities. In Linstead, S., Grafton Small, R. and Jeffcut, P. (Eds.). Understanding management: 157171. London: Sage.

Davies, B., and Harre, R. 1990. Positioning: The discursive Production of Selves. Journal for the Theory of Social Behavior, 20(1): 43-63. 
Diamond, M. 1988. Organizational identity: A psychoanalytic exploration of organizational meaning. Administration \& Society, 20(2): 166-190.

Diamond, M. 1993. The unconscious life of organizations: Interpreting organizational identity. Westport, CT: Quorum Books.

Driver, M. 2005. From empty speech to full speech? Reconceptualizing spirituality in organizations based on a psychoanalytically-grounded understanding of the self. Human Relations, 58(9): 1091-1110.

Driver, M. 2008. New and Useless: A Psychoanalytic Perspective on Organizational Creativity. Journal of Management Inquiry.

Driver, M. 2009. Encountering the Arugula Leaf: The Failure of the Imaginary and Its Implications for Research on Identity in Organizations. Organization, 16(4).

Dutton, J.E. and Dukerich, J.M. 1991. Keeping an eye on the mirror: Image and identity in organizational adaptation. Academy of Management Journal, 34(3): 517-554.

Elliott, A., and Frosh, S. 1995. Psychoanalysis in contexts. London: Routledge.

Elsbach, K.D. and Bhattacharya, C.B. 2001. Defining who you are by what you're not: Organizational disidentification and the National Rifle Association. Organization Scicene, 12(4): 393-413.

Elsbach, K.D. and Kramer, R.M. 1996. Members' responses to organizational identity threats: Encountering and countering the Business Week rankings. Administrative Science Quarterly, 41: 442-476.

Fink, B. 1995. The Lacanian subject. Princeton, NJ: Princeton University Press.

Fink, B. 1996. The subject and the other's desire. In Feldstein, R., Fink, B., and Jaanus, M. (Eds.) Reading seminars I and II: Lacan's return to Freud. Albany, NY: State University of New York: 76-97.

Fink, B. 2000. The analytic relationship. In Malone, K. R., and Friedlander, S.R. (Eds.). The subject of Lacan: A Lacanian reader for psychologists. Albany, NY: State University of New York Press: 157-172.

Fink, B. 2004. Lacan to the letter. Minneapolis, MN: University of Minnesota Press.

Fiol, C.M. 2001. Revisiting an identity-based view of sustainable competitive advantage. Journal of Management, 27: 691-699.

Fiol, C.M. 2002. Capitalizing on paradox: The role of language in transforming organizational identities. Organization Science, 13(6): 653-666. 
Fleming, P. and Spicer, A. 2003. Working at a cynical distance: Implications for power, subjectivity and resistance. Organization, 10(1), 157-179.

Gabriel, Y. et al. 1999. Organizations in depth. London: Sage.

Gallop, J. 1985. Reading Lacan. Ithaca, NY: Cornell University Press.

Gioia, D.A., Schultz, M. and Corley, K. 2000a. Organizational identity, image, and adaptive instability. Academy of Management Review, 25(1): 63-81.

Gioia, D.A., Schultz, M. and Corley, K. 2000b. Where do we go from here? Academy of Management Review, 25(1): 145-147.

Glynn, M.A. 2000. When cymbals become symbols: Conflict over organizational identity within a symphony orchestra. Organization Science, 11(3): 285-298.

Glynos, J. and Stavrakakis, Y. (Eds.). 2002. Lacan and Science. London: Karnac.

Golden-Biddle, K. and Rao, H. 1997. Breaches in the boardroom: Organizational identity and conflicts of commitment in a nonprofit organization. Organization Science, 8(6): 593-611.

Gustafson, L.T. and Reger, R.K. 1995. Using organizational identity to achieve stability and change in high velocity environments. Academy of Management Journal, 38: 464468.

Harding, N. 2007. On Lacan and the becoming-ness of organizations/selves. Organization Studies, 28(11): 1761-1773.

Haslam, S.A., Postmes, T. and Ellemers, N. 2003. More than a metaphor: Organizational identity makes organizational life possible. British Journal of Management, 14: 357-369.

Hatch, M.J. and Schultz, M. 2000. Scaling the tower of Babel: Relational differences between identity, image, and culture in organizations. In M.J. Hatch and M. Schultz (Eds.) The expressive organization. Oxford: Oxford University Press: 11-35.

Hatch, M.J. and Schultz, M. 2002. The dynamics of organizational identity. Human Relations, 55(8): 989-1018.

Hatch, M.J. and Yanow, D. 2007. Methodology by metaphor: Ways of seeing in painting and research. Working paper.

Holmer-Nadesan, M. 1997. Organizational identity and space of action. Organization Studies, 17(1): 49-81. 
Humphreys, M. and Brown, A.D. 2002. Narratives of organizational identity and identification: A case study of hegemony and resistance. Organization Studies, 23(3): 421-447.

Jones, C., and Spicer, A. 2005. The sublime object of entrepreneurship. Organization, 12: 223-246.

Kondo, D.K. 1990. Grafting selves: Power, gender and discourses of identity in a Japanese workplace. Chicago: University of Chicago Press.

Kosmala, K. and Herrbach, O. 2006. The ambivalence of professional identity: On cynicism and jouissance in audit firms. Human Relations, 59(10): 1393-1428.

Lacan, J. 1977a. Ecrits. New York: Norton.

Lacan, J. 1977b. The four fundamental concepts of psychoanalysis. London: Hoghart Press.

Lacan, J. 1988a. The seminar of Jacques Lacan, Book I: Freud's papers on technique 1953-1954. New York: Norton.

Lacan, J. 1988b. The seminar of Jacques Lacan, Book II: The ego in Freud's theory and in the technique of psychoanalysis 1954-1955. New York: Norton.

Lacan, J. 1991. Le seminaire de Jacques Lacan 1969-1970, Livre XVII: L'envers de la psychanalyse. Paris: Editions Du Seuil.

Lacan, J. 2001. Autres ecrits. Paris: Editions Du Seuil.

Lefebvre, H. 1991. The production of space. Oxford: Blackwell.

Loose, R. 2002. A Lacanian approach to clinical diagnosis and addiction. In Glynos, J., and Stavrakakis, Y. (Eds.) Lacan and Science. London: Karnac: 263-289.

Maravelias, C. 2003. Post-bureaucracy - Control through professional freedom. Journal of Organizational Change Management, 16(5): 547-566.

Muller, J.P., and Richardson, W.J. 1982. Lacan and Language. New York: International University Press.

Nobus, D. 2002. A matter of cause: reflections on Lacan's "Science and truth". In Glynos, J., and Stavrakakis, Y. (Eds.) Lacan and Science. London: Karnac: 89-118.

Pratt, M.G. and Foreman, P.O. 2000. Classifying managerial responses to multiple organizational identities. Academy of Management Review, 25(1): 18-42. 
Pratt, M.G. and Rafaeli, A. 1997. Organizational dress as a symbol of multilayered social identities. Academy of Management Journal, 40(4): 862-898.

Ragland, E. 1996. An overview of the real, with examples from seminar I. In Feldstein, R., Fink, B., and Jaanus, M. (Eds.) Reading seminars I and II: Lacan's return to Freud. Albany, NY: State University of New York: 192-211.

Ravasi, D. and Schultz, M. 2006. Responding to organizational identity threats: Exploring the role of organizational culture. Academy of Management Journal, 49(3): 433-458.

Roberts, J. 2005. The power of the 'imaginary' in disciplinary processes. Organization, 12(5): 621-645.

Rustin, M. 1995. Lacan, Klein and politics. In Elliott, A., and Frosh, S. (Eds.)

Psychoanalysis in contexts. London: Routledge: 223-245.

Schwartz, H.S. 1990. Narcissistic process and corporate decay: The theory of the organizational ideal. New York: New York University Press.

Scott, S.G. and Lane, V.R. 2000a. A stakeholder approach to organizational identity. Academy of Management Review, 25(1): 43-62.

Scott, S.G. and Lane, V.R. 2000b. Fluid, fractured, and distinctive? In search of a definition of organizational identity. Academy of Management Review, 25(1): 143-144.

Sillince, J.A.A. 2006. Resources and organizational identities: The role of rhetoric in the creation of competitive advantage. Management Communication Quarterly, 20(2): 186212.

Simon, B. and Oakes, P. 2006. Beyond dependence: An identity approach to social power and domination. Human Relations, 59(1): 105-139.

Soler, C. 1996. The symbolic order. In Feldstein, R., Fink, B., and Jaanus, M. (Eds.) Reading seminars I and II: Lacan's return to Freud. Albany, NY: State University of New York: 47-75.

Thomas, R. and Davies, A. 2005. Theorizing the micro-politics of resistance: New public management and managerial identities in the UK public services. Organization Studies, 26(5): 683-706.

Sveningsson, S. and Alvesson, M. 2003. Managing managerial identities: Organizational fragmentation, discourse and identity struggle. Human Relations, 56(10): 1163-1180.

Vanheule, S. 2006. Neurotic depressive trouble: In between the signifier and the real. Working paper. 
Vanheule, S., Lievrouw, A., and Verhaeghe, P. 2003. Burnout and intersubjectivity: A psychoanalytical study from a Lacanian perspective. Human Relations, 56(3), 321-338.

Verhaeghe, P. 1999. Does the woman exist? From Freud's hysteric to Lacan's feminine. New York: Other Press.

Verhaeghe, P. 2001. Beyond gender. New York: Other Press.

Verhaeghe, P. 2006. Enjoyment and impossibility: Lacan's revision of the Oedipal complex. In Clemens, J. and Grigg, R. (Eds.). Jacques Lacan and other side of psychoanalysis. Durham, NC: Duke University Press.

Whetten, D.A. 2006. Albert and Whetten revisited: Strengthening the concept of organizational identity. Journal of Management Inquiry, 15(3): 219-234. 